\title{
Sperm storage and mating in the deep-sea squid Taningia danae Joubin, 1931 (Oegopsida: Octopoteuthidae)
}

\author{
Hendrik Jan T. Hoving • Marek R. Lipinski • \\ John J. Videler · Kat S. R. Bolstad
}

Received: 10 February 2009 / Accepted: 9 October 2009 / Published online: 10 November 2009

(C) The Author(s) 2009. This article is published with open access at Springerlink.com

\begin{abstract}
Spermatangium implantation is reported in the large oceanic squid Taningia danae, based on ten mated females from the stomachs of sperm whales. Implanted spermatangia were located in the mantle, head and neck (on both sides) or above the nuchal cartilage, under the neck collar and were often associated with incisions. These cuts ranged from 30 to $65 \mathrm{~mm}$ in length and were probably made by males, using the beak or arm hooks. This is the first time wounds facilitating spermatangium storage have been observed in the internal muscle layers (rather than external, as observed in some other species of squid). The implications of these observations for the mating behavior of the rarely encountered squid $T$. danae are discussed.
\end{abstract}

\section{Introduction}

Some deep-sea squid are rarely encountered, and the biology of many species remains poorly understood. Observations of live specimens are even rarer, and the examination of dead

Communicated by U. Sommer.

H. J. T. Hoving $(\bowtie) \cdot$ J. J. Videler

Ocean Ecosystems, Centre for Ecological and Evolutionary

Studies, University of Groningen, P.O. Box 14,

9750 AA Haren, The Netherlands

e-mail: h.j.t.hoving@rug.nl

\section{R. Lipinski}

Department of Environmental Affairs and Tourism,

Private Bag X2, Roggebaai 8012, Cape Town 8000, South Africa

\section{K. S. R. Bolstad}

Earth \& Oceanic Sciences Research Institute,

Auckland University of Technology,

Private Bag 92006, Auckland 1142, New Zealand animals, whether washed ashore, caught by fishing gear or retrieved from stomachs of large predators, remains an important source of biological information. The octopoteuthid squid Taningia danae Joubin, 1931, which may reach $124 \mathrm{~kg}$ (González et al. 2003) is one such poorly studied deep-sea species. Recently, one live specimen was photographed (Kubodera et al. 2007), but otherwise the species is mainly known from the stomach contents of sperm whales and sharks (Clarke 1996). Descriptions in the literature of trawl-caught, fresh material include only two mature males, two mature females, two maturing females and 20 juveniles (Okutani 1974; Roper and Vecchione 1993; Santos et al. 2001; González et al. 2003; Quetglas et al. 2006). This study presents the first detailed information on sperm transfer and storage in T. danae.

Reproduction in cephalopods is characterized by separation of the sexes and semelparity, i.e., gonad maturation and spawning (although sometimes protracted), occur once at the end of the animal's life (Nesis 1987). Spermatozoa are packed into complex spermatophores, which are transferred to the female by the hectocotylus (a modified arm) or, in species lacking a hectocotylus, by a long terminal organ (an extension of Needham's sac, the storage organ for spermatophores) (Nesis 1995). During mating, the spermatophore is transferred and then everts after initiation of the 'spermatophoric reaction' (reported in Loligo pealei by Drew (1919), Octopoteuthis sicula by Hoving et al. (2008b) and Todarodes pacificus by Takahama et al. (1991)). This reaction begins when the spermatophore is removed from the Needham's sac by the hectocotylus; in unhectocotylized species, the distal tip of the long terminal organ triggers the reaction as the spermatophore exits its aperture (observed in Onykia ingens by Hoving and Laptikhovsky (2007)). The spermatangium, which is the sperm mass enveloped in an outer casing (the 'inner tunic' sensu Drew 1919), is then 
expelled from the spermatophore and deposited on the body of the female. The remaining empty sheath of the spermatophore is lost. Spermatangium attachment locations and mechanisms are species and family specific (Nesis 1995; Hoving 2008); spermatangia may be attached at consistent external sites on the female (the buccal membrane or mantle) or in special seminal receptacles. In some species, spermatangia are deposited seemingly non-selectively over the female's exterior body surfaces (Nesis 1995; Hoving et al. 2004; Hoving 2008) and are often deeply implanted into the female's tissues, while spermatangia deposited at specific consistent sites are generally superficially attached (Nesis 1995).

In hectocotylized squids, the male probably holds everting spermatophores against the preferred deposition site, and the spermatangia then attach to the female's tissues. In species lacking a hectocotylus, the terminal organ positions the everting spermatophores. The exact mechanism by which spermatangia attach to and implant into female tissues remains poorly understood. In some species, attachment is aided by extensions on the oral side of the spermatangium, which penetrate the female's tissues [e.g., Todarodes pacificus (Takahama et al. 1991) and Octopoteuthis sicula (Hoving et al. 2008b)]. In some onychoteuthids, implanted spermatangia are associated with elongated exterior wounds on the female's mantle (Torchio 1967; Nesis 1970; Clarke 1980; Okutani and Ida 1986; Bolstad 2008; Bolstad and Hoving submitted), which may be created by the male's beak (Torchio 1967). Although Norman and $\mathrm{Lu}$ (1997) speculated that Architeuthis sp. implants spermatangia deeply into female tissues under hydraulic pressure produced by the terminal organ, recent studies have shown that some squid spermatangia implant autonomously (Hoving and Laptikhovsky 2007; Hoving et al. 2009). Such autonomous implantation may be enabled or aided by proteolytic enzymes present in the spermatophore's cement body (Nesis et al. 1998).

Fertilization occurs externally in squid, since spermatangia are stored outside of the perivisceral coelom and oviducts (Hanlon and Messenger 1996). In loliginids, two spermatangium storage sites exist-the buccal membrane and the distal oviduct - and spawned eggs are passed along both sites for fertilization. The fertilization mechanisms in oceanic squid remain unknown.

Taningia danae is one such species. Mature males, which lack a hectocotylus, presumably use the long terminal organ (Okutani 1974; González et al. 2003) to transfer spermatophores to the female. González et al. (2003) provided the only information available on spermatophores of T. danae, reporting one intact spermatophore of $54 \mathrm{~mm}$ length and one everted spermatophore of $166 \mathrm{~mm}$ length; the actual morphology of the spermatophores remains undescribed. Although the implantation of spermatangia into the arms, head and mantle has been reported for a variety of oceanic squid species (Nesis 1970, 1995; Clarke 1980; Okutani and Ida 1986; Norman and Lu 1997; Guerra et al. 2004; Jackson and Jackson 2004; Hoving et al. 2004, 2008b; O'Shea et al. 2007; Bolstad 2008) including T. danae (Clarke 1967; Okutani 1974), implanted spermatangia associated with male-inflicted wounds have never been reported for this species.

\section{Materials and methods}

At Iziko Museums of Cape Town, nine specimens of T. danae were examined from the stomachs of three sperm whales commercially caught in South African waters off Durban, between 1970 and 1973. Another twelve specimens, accessioned in the Museum of Natural History (London), were examined; these specimens had been collected from the stomachs of sperm whales caught in South African waters between 1963 and 1965. After collection from the stomachs, all ex-sperm-whale specimens were stored in $10 \%$ formalin and later transferred to ethyl alcohol. Although these specimens were not in good condition, their anatomical features and organs could be differentiated. One additional specimen was examined from New Zealand waters, caught August 26, 2003, by midwater trawl at $365 \mathrm{~m}$ (fishing both in midwater and on the bottom), between $41^{\circ} 59.1^{\prime} \mathrm{S}-170^{\circ} 35.6 \mathrm{E}^{\prime}$ and $41^{\circ} 52.3 \mathrm{~S}^{\prime}-170^{\circ} 36.6^{\prime} \mathrm{E}$. This specimen is accessioned in the Museum of New Zealand Te Papa Tongarewa under NMNZ M.284745. Details of all mated females reported herein are given in Table 1.

\section{Results}

Mated Taningia danae from stomachs of sperm whales caught in 1970-1973

Seven females (Table 1) bore bundles of spermatangia (discharged spermatophores) or remains of spermatangia implanted in the mantle, nuchal region and nearby regions of the head and neck (Fig. 1). The spermatangia, and some tunics without sperm, were found in bundles of approximately 20-40 (Fig. 2a; Table 1). Each intact spermatangium consisted of a sperm reservoir (length $2-5 \mathrm{~mm}$ ) at the oral end (i.e., reversed orientation from the spermatophore) that gradually narrowed aborally and extended into a tunic approximately $1 \mathrm{~mm}$ wide. The oral end was typified by the presence of a filament (Fig. 2b) that extended, closely adherent, along the sperm reservoir aborally (similar to the morphology of implanted spermatangia of Octopoteuthis sicula; see Hoving et al. 2008b). This filament was often 
Table 1 Information on mated female Taningia danae from South African sperm whale stomachs

\begin{tabular}{|c|c|c|c|}
\hline $\begin{array}{l}\text { Catalog no. and } \\
\text { collection details }\end{array}$ & $\begin{array}{l}\text { Specimen } \\
\text { ID }\end{array}$ & $\begin{array}{l}\mathrm{DML} \\
(\mathrm{mm})\end{array}$ & $\begin{array}{l}\text { Location of implanted spermatangia/ } \\
\text { tunics and (length of cuts) }\end{array}$ \\
\hline $\begin{array}{l}\text { SAM-S2589, Sperm whale } \\
\text { caught at } 31^{\circ} 16^{\prime} \mathrm{S} \\
30^{\circ} 53^{\prime} \mathrm{E} \text { on } 16-\mathrm{VII}-1973\end{array}$ & 1 & - & $\begin{array}{l}\text { Spermatangia in both sides of nuchal cartilage } \\
\text { under neck collar in cut }(50-55 \mathrm{~mm}) \text {, with corresponding } \\
\text { cut }(50 \mathrm{~mm}) \text { in dorsal inner mantle; additionally on left side } \\
\text { in dorsal neck in cut }(45 \mathrm{~mm}) \text {, with corresponding cut } \\
(45 \mathrm{~mm}) \text { in dorsal inner mantle }\end{array}$ \\
\hline \multirow[t]{5}{*}{$\begin{array}{l}\text { SAM-S2778, Sperm whale } \\
\text { caught at } 30^{\circ} 43^{\prime} \mathrm{S} \\
31^{\circ} 01^{\prime} \mathrm{E} \text { on } 16-\mathrm{IX}-1970\end{array}$} & 2 & $>630$ & $\begin{array}{l}\text { Tunics in dorsal neck just above nuchal cartilage in cut }(50 \mathrm{~mm}) \text {; } \\
\text { under neck collar on right side of nuchal cartilage } \\
\text { in cut }(30 \mathrm{~mm}) \text {; in dorsal surface of head }\end{array}$ \\
\hline & 3 & $>600$ & $\begin{array}{l}\text { Spermatangia under neck collar on left side of nuchal cartilage } \\
\text { in cut ( } 40 \mathrm{~mm}) \text {; on inside surface of mantle } 500 \mathrm{~mm} \text { from } \\
\text { anterior tip of nuchal cartilage; tunics implanted in dorsal } \\
\text { surface of head }\end{array}$ \\
\hline & 4 & $>900$ & $\begin{array}{l}\text { Spermatangia in inner mantle margin on left side; } \\
\text { tunics implanted in dorsal surface of head }\end{array}$ \\
\hline & 5 & $>960$ & $\begin{array}{l}\text { Tunics above neck collar in dorsal cut }(65 \mathrm{~mm}) \text {; } \\
\text { dorsal to right eye in cut }(50 \mathrm{~mm})\end{array}$ \\
\hline & 6 & $>700$ & Tunics implanted in dorsal surface of head \\
\hline SAM-S3450, no locality data & 7 & 540 & $\begin{array}{l}\text { Tunics on left side of nuchal cartilage under neck } \\
\text { collar in cut }(45 \mathrm{~mm}) \text {; right side of nuchal cartilage } \\
\text { under neck collar in two cuts }(50 \mathrm{~mm})\end{array}$ \\
\hline Durban 1963-2262 & 8 & - & $\begin{array}{l}\text { Five incisions: two transverse cuts in exterior surface } \\
\text { of head/collar musculature, one ventrally near } \\
\text { funnel }(55 \mathrm{~mm}) \text {, one laterally posterior to eye }(65 \mathrm{~mm}) \text {; } \\
\text { one transverse cut in head musculature under collar on } \\
\text { each side of dorsal midline (right cut } 32 \mathrm{~mm} \text {, left cut } 35 \mathrm{~mm}) \text {, } \\
\text { with associated cut into head of same length beneath; } \\
\text { one transverse (slightly diagonal) cut }(35 \mathrm{~mm}) \text { just posterior } \\
\text { to collar muscle; additional individual spermatangia loose } \\
\text { and implanted throughout body cavity }\end{array}$ \\
\hline D3228 & 9 & - & $\begin{array}{l}\text { Three incisions: two transverse cuts (each } 40 \mathrm{~mm} \text { ) under } \\
\text { collar muscle (one dorsal, just right of dorsal cartilage, } \\
\text { with } \sim 15 \text { deeply embedded spermatangia; one lateral, } \\
\text { on left-hand side of head, approximately halfway between } \\
\text { dorsal cartilage and funnel cartilage, with } \sim 10 \text { implanted } \\
\text { spermatangia); one slightly diagonal transverse cut in } \\
\text { interior of mantle wall, } 33 \mathrm{~mm} \text { long and } 9 \mathrm{~mm} \text { deep, } \\
\text { posterior and slightly lateral to dorsal nuchal cartilage, } \\
\text { with } \sim 12 \text { spermatangia. } \sim 30 \text { spermatangia also implanted } \\
\text { singly into dorsolateral surface of head, obliquely } \\
\text { under skin, within a small, contained area }\end{array}$ \\
\hline $\begin{array}{l}\text { Squid D3256, } \\
\text { ex 50' sperm whale (M), } \\
\text { 03/08/1965, } \\
\text { M.R. Clarke } \\
\text { Collection (Acc. 2366), }\end{array}$ & 10 & 550 & $\begin{array}{l}\text { Two incisions: one on either side of midline dorsolaterally, } \\
\text { under collar musculature, with associated spermatangia }\end{array}$ \\
\hline
\end{tabular}

broken and could only be seen as a "knob" extending from the oral end. The total length of each spermatangium was over $50 \mathrm{~mm}$. Most were deeply embedded into the tissue or tangled with other spermatangia.

In five specimens, spermatangia were implanted in, or associated with, incisions of $30-65 \mathrm{~mm}$ in length, in the following areas: head and dorsal nuchal region, inner collar muscle and head retractor muscle, and on one or both sides of the nuchal cartilage, underneath the intact mantle and the outer neck collar (Table 1; Figs. 1, 3, 4). Each individual bore one to three incisions in the dorsal neck region, which could only be seen when the dorsal mantle was folded posteriorly and the collar beneath the mantle was folded anteriorly (Fig. 3). In the head retractor muscle, bundles of spermatangia extended through the muscle, in some cases into the digestive gland (Figs. 1, 3). 


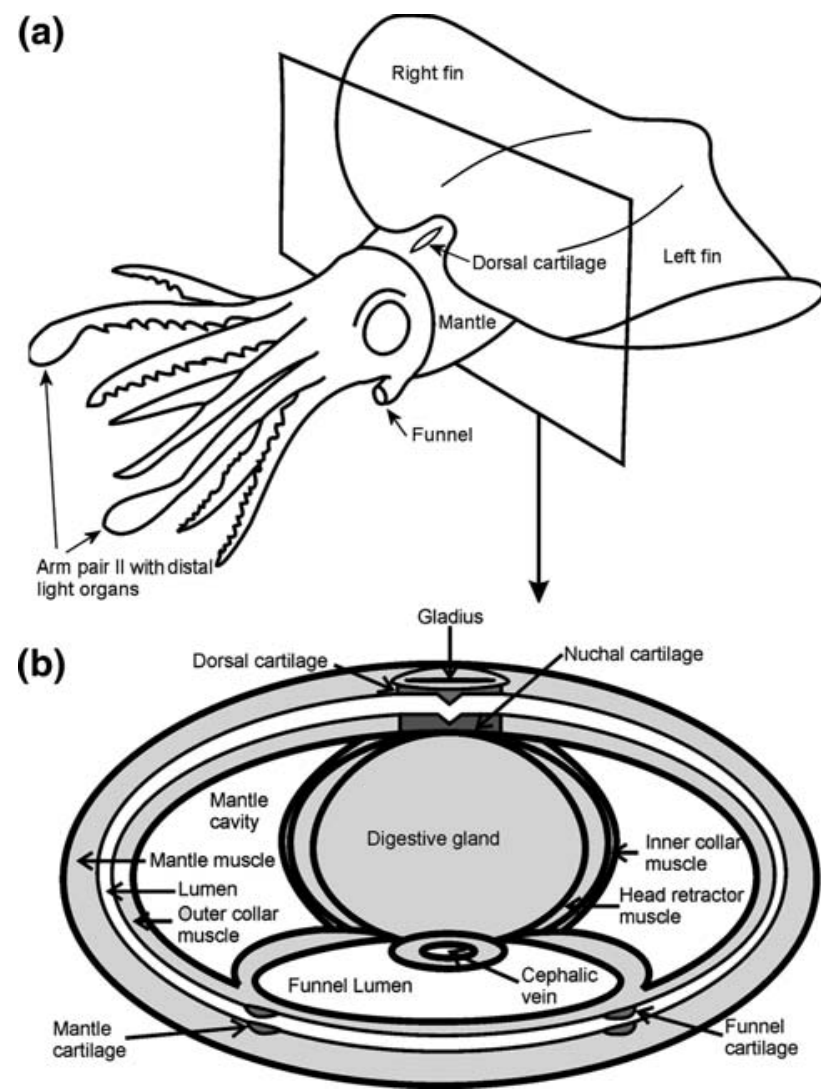

Fig. 1 (a) Taningia danae (based on drawing by R. Ellis 1998) with indication of $(\mathbf{b})$ schematic representation of a cross section of the neck region (modified from Sepia officinalis (Thompsett, 1939)

In one female, two of the three cuts in the dorsal neck region corresponded to similar cuts on the inner dorsal mantle wall. The lengths of these latter cuts matched those of the corresponding, spermatangia-bearing neck cuts; their depth extended up to $10 \mathrm{~mm}$ into the dorsal mantle wall, but did not break its inner surface (Fig. 3).
Mated Taningia danae from stomachs of sperm whales caught in 1963-1965

Two partial specimens bearing evidence of mating were observed, each comprised of arms, head and anterior $\sim 30 \%$ of mantle with associated ragged viscera (but could not be sexed); the arm lengths of each measured $\sim 20 \mathrm{~cm}$. Incisions (up to five in one specimen) and associated spermatangia (Fig. 4d) were observed as above, both under the collar musculature and in the head and inner mantle musculature (Fig. 4a, b; Table 1). Individually implanted spermatangia, not associated with incisions, were also observed in the dorsal head (Fig. 4c).

One additional complete, spent female (ML $550 \mathrm{~mm}$ ) was found. All tissues were greatly atrophied and loosened; the fins and mantle were so thin as to be quite translucent, and the funnel was so greatly stretched as to cover the entire ventral surface of head, with the aperture level with the arm tips (Fig. 5a). The epidermis of the dorsal fin surfaces was densely studded with small nodules (Fig. 5b), cartilaginous in consistency (approximately 100 per square centimeter); these structures were unapparent elsewhere on the specimen. Two incisions with associated spermatangia were present, one on either side of midline dorsolaterally under the collar musculature.

\section{Trawled specimen}

The trawled $T$. danae specimen was a maturing female, ML $650 \mathrm{~mm}$. Small oocytes were present in the ovary, and the developing nidamental glands were $245 \mathrm{~mm}$ long. One incision, $65 \mathrm{~mm}$ in length, was observed underneath the collar musculature, almost directly below the right-hand funnel component of the locking apparatus (Fig. 3c), resembling the incisions found in the specimens from the whale stomachs. Although the specimen's head was in poor condition, the cut appeared clean and traversed the depth of the musculature, creating a "window" through to the digestive
Fig. 2 Taningia danae. a Nuchal area of a mated female (SAM-S2589), ventral view, showing the oral ends of implanted spermatangia. b Detail of the oral end of the spermatangium showing the oral filament (of) that extends, closely adherent, along the sperm reservoir aborally
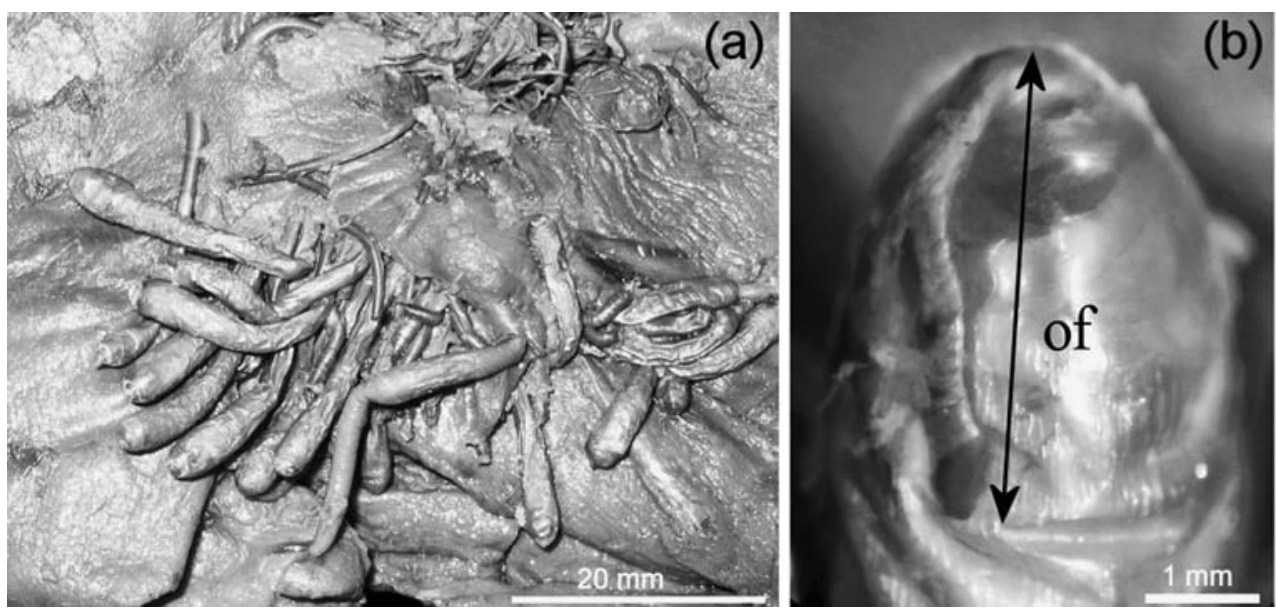
Fig. 3 Taningia danae. a Dorsal view of the dorsal neck region with the anterior mantle folded posteriorly. NC, nuchal cartilage; MC, mantle counterpart of the nuchal cartilage (i.e., the dorsal cartilage); OCM, outer collar muscle; HR, head retractor mus$\mathrm{AM}$, anterior mantle; 1 cut with spermatangia; 2 cut with spermatangia in inner collar muscle; $2^{\prime}$ cut in anterior inner mantle corresponding with cut 2 in inner collar muscle. b As in (a), but with free trailing ends of the implanted spermatangia revealed. c Incision beneath right-hand funnel component of the locking apparatus, in the trawl-caught maturing female cle; ICM, inner collar muscle;
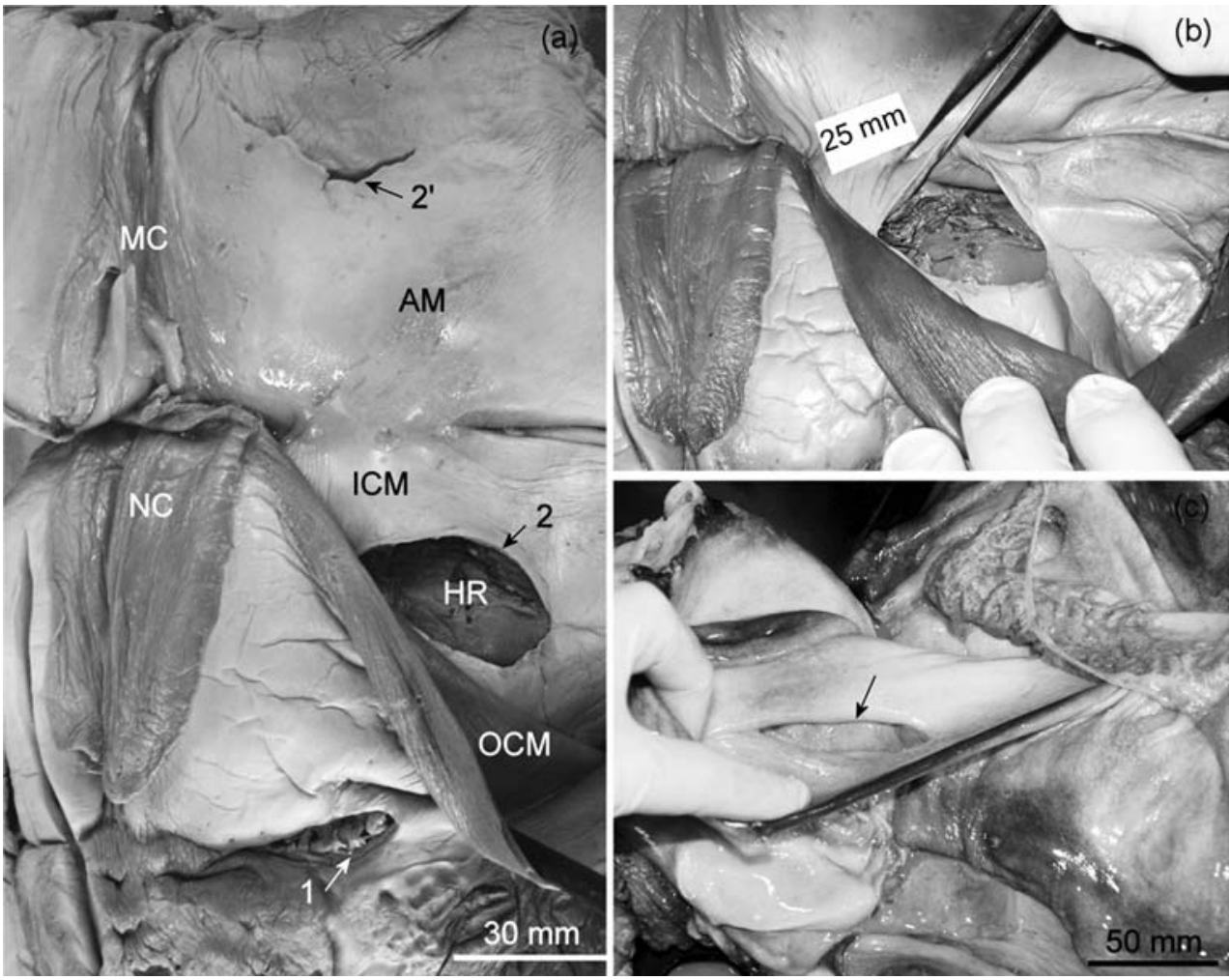

Fig. 4 Taningia danae. a Incision in the inner collar muscle and underlying tissue, with associated implanted spermatangia (aboral trailing ends of the spermatangia are visible). b Incision with associated implanted spermatangia in the inner mantle wall surface. c Dorsal head surface with individually implanted spermatangia (indicated by white arrows). d Spermatangia and parts of spermatangia removed from incision. The oral filament (of) and trailing end (te) are indicated
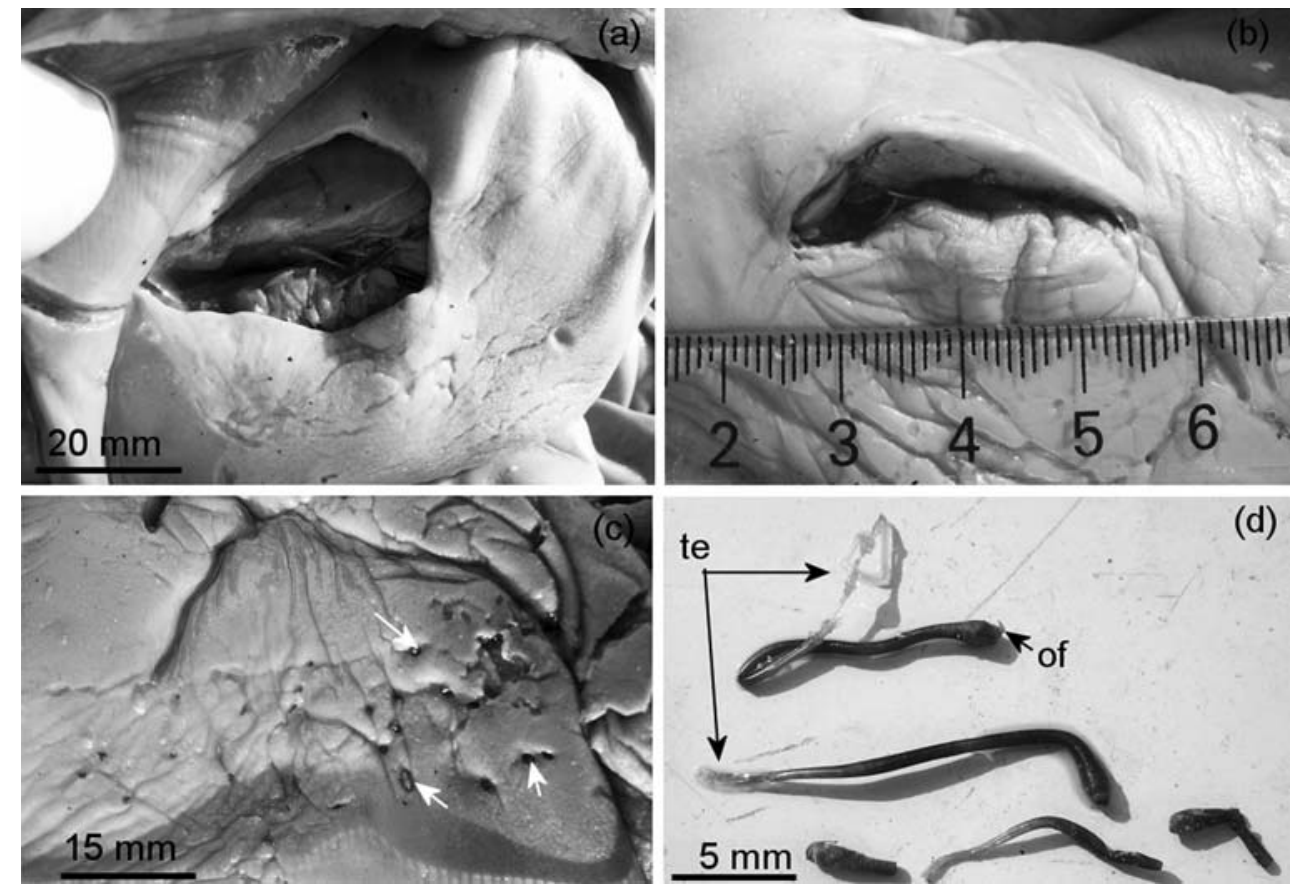

gland. No implanted spermatangia were found inside the cut or elsewhere in/on this specimen.

\section{Discussion}

The presence of consistent wounds in several large female T. danae specimens is suggestive. Since the trawled speci- men bore an incision, but did not have any implanted spermatangia, we cannot conclude that its wound was necessarily mating related. However, the wounds in the other female $T$. danae were clearly the result of mating or attempted mating, since they were all associated with implanted spermatangia. Large wounds and associated implanted spermatangia have been observed in several other squid species (of the genus Onychoteuthis, see Nesis 
Fig. 5 Taningia danae. a Spent female (ML $550 \mathrm{~mm}$ ) with greatly enlarged funnel $(\mathrm{F}$, indicated by arrow). M, mantle; E, eye; A, arms. b Epidermis of the dorsal fin surface, densely studded with small nodules. Major increments shown $=10 \mathrm{~mm}$
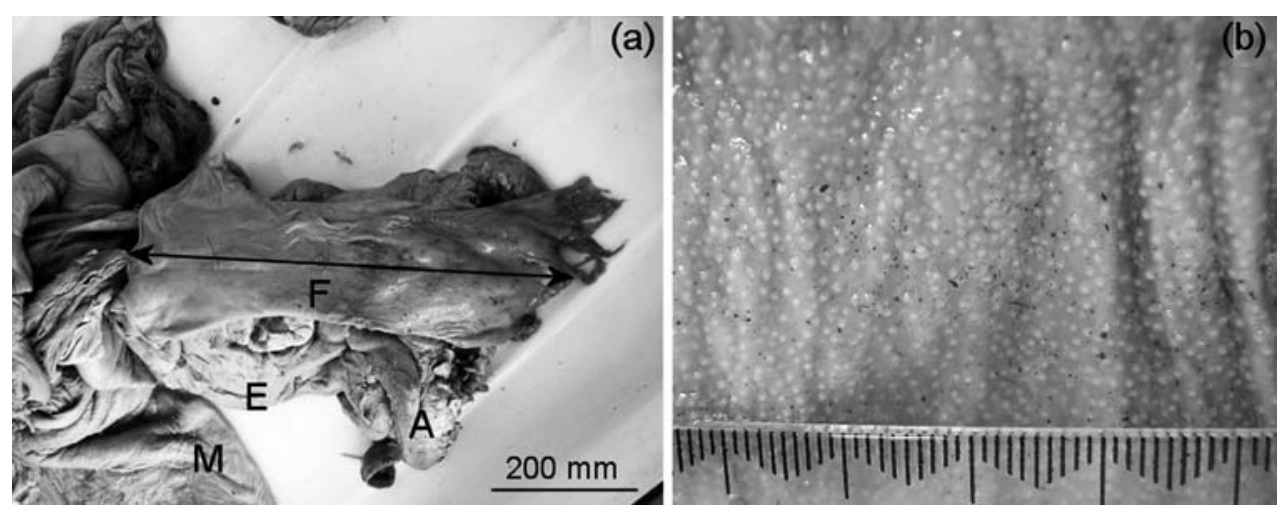

1970; Clarke 1980; Okutani and Ida 1986; Bolstad 2008; Bolstad and Hoving submitted). However, in these cases, the wounds occurred in the outer mantle surface, while in $T$. danae, the cuts are found underneath two layers of intact tissue. The position of the incisions in $T$. danae indicates that the anterior mantle edge and the underlying collar must be somehow held aside while the incisions are created, perhaps by the arm hooks or the beak. On basis of the mandible dimensions, Torchio (1967) argued that the wounds in the outer mantle surface of 'Chaunoteuthis' mollis were made by the beak. In our $T$. danae specimens, the size of the wounds $(30-65 \mathrm{~mm})$ could also correspond to the male's beak.

We assume that the long, muscular terminal organ (which can extend well out of the mantle cavity of the male (Okutani 1974; González et al. 2003) is used to deposit the spermatophores into the wounds. The spermatophoric reaction may be triggered by the tip of the muscular terminal organ, as observed in Onykia ingens (Hoving and Laptikhovsky 2007). The spermatangia would then discharge from the spermatophores and implant into the head retractor muscle and viscera in $T$. danae, or in other locations such as the head and mantle; the exact mechanism of implantation is restricted to speculation. Not all implanted spermatangia were associated with cuts, indicating that cuts are not required for implantation. Spermatophores of $T$. danae may be capable of implanting autonomously into body tissue, as observed in the deep-sea squid Onykia ingens (Hoving and Laptikhovsky 2007), possibly aided by the oral filament (Fig. 2b). This filament may either penetrate the tissue and/or distribute the possibly caustic cement expelled during the spermatophoric reaction. This implantation scenario has also been proposed for Octopoteuthis sicula (Hoving et al. 2008b), a confamilial species with similar spermatangium morphology to $T$. danae.

The incisions made by male $T$. danae may ensure that everting spermatophores have sufficient contact with the female's tissue to ensure successful implantation. The nuchal region seems to be the preferred implantation site for $T$. danae, since most spermatangia are found there (in the dorsal head and neck region, in the outer neck collar, and under the outer neck collar, and in the underlying head retractor muscle). Deposition of spermatangia in the region of the nuchal cartilage is also known for smaller mesopelagic squid of the families Lycoteuthidae and Enoploteuthidae (Burgess 1998; Hoving et al. 2007). However, these squid have special areas or pockets (seminal receptacles) in the nuchal region for the reception and storage of spermatangia, and the males do not make wounds. As with most other deep-sea squid, the method by which females of $T$. danae access the sperm when they are ready to spawn is not known. Sperm may become mobile after exposure to chemical cues from the female (e.g., a nidamental gland secretion), as has been suggested for Illex illecebrosus (Durward et al. 1980). The spermatozoa appear to exit the spermatangium through the aboral opening of the free trailing end, which opens in the nuchal area. After coating the spawned eggs with oviducal and nidamental gland secretion, female $T$. danae could draw their eggs from the mantle cavity along both sides of the neck, where the spermatangia would open, releasing spermatozoa to fertilize the eggs. A similar spawning and fertilization process has been described for enoploteuthid squids (Nesis 1995).

Copulatory struggles between the sexes have been previously reported in other oceanic squids. In one female Bathothauma lyromma, two long arms were found attached to the inner mantle wall, these may have been bitten off during a copulation attempt (Young 1978, cited by Voss 1985 and again in Nesis 1995). Voss (1985) also observed scars and encysted suckers on the inner dorsal and ventral mantle wall surfaces, as well as on the exposed internal organs of the cranchiid squid Teuthowenia pellucida. All mature males of T. pellucida examined in the same study showed recent loss of body parts, although Arms I, and usually Arms II (the two pairs of modified arms), were always intact, suggesting that they may have been inside the mantle of the female during mating, when the injuries were sustained. An examination of the stomach contents revealed that the stomachs of two females were distended with recently consumed flesh, and pieces of gladii and 
spermatophores identifiable to T. pellucida. Voss (1985) suggested this as an artifact due to trauma in the trawl and also indicated that cannibalism may occur during mating.

Similar reports exist for three additional families. Both female and male specimens of Heteroteuthis dispar have been observed with large sucker scars on their heads, probably as a result of copulation attempts (Orsi Relini 1995; Hoving et al. 2008a). Mating male and female specimens of Onykia ingens, with interlocking beaks, were described by Jackson and Jackson (2004) and Bolstad (2006). And finally, O'Shea et al. (2007) reported that implanted spermatangia in specimens of Pholidoteuthis massyae were associated with dermal abrasion and removal of the dermal papillae consistent with male beak rasping, and less severe papillar abrasion consistent with male arm sucker rings.

It appears that successful mating in $T$. danae may similarly entail injury for at least one of the individuals involved. Although the empty incision observed in the trawl-caught specimen, and the non-incision-associated bundles of spermatangia in two of the ex-whale specimens, are far from conclusive, it is not difficult to envision an unsuccessful mating attempt in which such incisions or incisionless implantations might arise. The sexual size dimorphism in $T$. danae is female biased, which may make wounding the female during copulation a risky strategy for the male, and cannibalism (by females) is known for several squid species (e.g., Jackson et al. 1998; Bolstad and O'Shea 2004; Deagle et al. 2005). The nuchal region underneath the outer collar is a small, specific and not immediately accessible target; and the implantations in the exterior of the head and neck could result failed or foreshortened attempts to access the 'usual' site.

Acknowledgments This study was financially supported by the Schure-Beijerinck-Popping funds (Royal Dutch Academy of Sciences) and the Nicolaas Mulerius Funds (University of Groningen). We also thank José Lamain for her help during dissection of the animals; Deniz Haydar and Prof. Dr. R. E. Young for critically reading the manuscript and providing supportive criticism; Mr. Summerfield for collecting the trawled specimen; and Serena Donati for translating Torchio (1967). This study is dedicated to Martina. A. C. Roeleveld, who sadly passed away during preparation of this work.

Open Access This article is distributed under the terms of the Creative Commons Attribution Noncommercial License which permits any noncommercial use, distribution, and reproduction in any medium, provided the original author(s) and source are credited.

\section{References}

Bolstad KS (2006) Sexual dimorphism in the beaks of Moroteuthis ingens Smith, 1881 (Cephalopoda: Oegopsida: Onychoteuthidae). N Z J Zool 33:317-327

Bolstad KS (2008) Systematics of the Onychoteuthidae Gray, 1847 (Cephalopoda: Oegopsida). Auckland University of Technology, pp 1-264
Bolstad KS, O'Shea S (2004) Gut contents of a giant squid Architeuthis dux (Cephalopoda: Oegopsida) from New Zealand waters. N Z J Zool 31:15-21

Burgess LA (1998) A survey of seminal receptacles in the Enoploteuthidae. In: Voss NA et al (ed) Systematics and biogeography of cephalopods, vol 1. Smiths Contr Zool 586: 271-276

Clarke MR (1967) A deep-sea squid, Taningia danae Joubin, 1931. Symp Zool Soc Lond 19:127-143

Clarke MR (1980) Cephalopoda in the diet of sperm whales of the southern hemisphere and their bearing on sperm whale biology. Discov Rep 37:1-324

Clarke MR (1996) Cephalopods in the world's oceans: Cephalopods as prey. III. Cetaceans. Philos Trans R Soc Lond B Biol Sci 351:1053-1065

Deagle BE, Jarman N, Pemberton D, Gales NJ (2005) Genetic screening for prey on the gut contents from a giant squid (Architeuthis sp.). J Hered 96(4):417-423

Drew GA (1919) Sexual activities of the squid Loligo pealii (Les.). II. The spermatophore; its structure, ejaculation and formation. J Morphol 32:379-435

Durward RD, Vessey E, O’Dor RK, Amaratunga T (1980) Reproduction in the squid, Illex illecebrosus: first observations in captivity and implications for the life cycle. International Commission for the Northwest Atlantic Fisheries Selected Papers (6): 7-13

Ellis R (1998) The search for the giant squid. Penguin Books, $322 \mathrm{p}$

González ÁF, Guerra Á, Rocha F (2003) New data on the life history and ecology of the deep-sea hooked squid Taningia danae. Sarsia $88: 297-301$

Guerra Á, González ÁF, Dawe EG, Rocha F (2004) Records of giant squid in the north-eastern Atlantic, and two records of male Architeuthis sp. off the Iberian Peninsula. J Mar Biol Assoc UK 84:427-431

Hanlon RT, Messenger JB (1996) Cephalopod behavior. University Press, Cambridge

Hoving HJT (2008) Reproductive biology of oceanic decapodiform cephalopods. PhD thesis, University of Groningen, pp 1-184

Hoving HJT, Laptikhovsky V (2007) Getting under the skin: autonomous implantation of squid spermatophores. Biol Bull 212:177179

Hoving HJT, Roeleveld MAC, Lipinski MR, Melo Y (2004) Reproductive system of the giant squid Architeuthis in South African waters. J Zool Lond 264:153-169

Hoving HJT, Lipinski MR, Roeleveld MAC, Durholtz MD (2007) Growth and mating of Lycoteuthis lorigera (Steenstrup, 1875) (Cephalopoda; Lycoteuthidae). Rev Fish Biol Fish 17(2-3):259-270

Hoving HJT, Laptikhovsky V, Piatkowski U, Önsoy B (2008a) Reproduction in Heteroteuthis dispar (Rüppell, 1844) (Mollusca: Cephalopoda): a sepiolid reproductive adaptation to an oceanic lifestyle. Mar Biol 154:219-230

Hoving HJT, Lipinski MR, Videler JJ (2008b) Reproductive system and the spermatophoric reaction of the mesopelagic squid Octopoteuthis sicula (Rüppell, 1844) (Cephalopoda: Octopoteuthidae) from southern African waters. Afr J Mar Sci 30(3):603-612

Hoving HJT, Nauwelaerts S, van Genne B, Stamhuis EJ, Zumholz K (2009) Spermatophore implantation in Rossia moelleri Steenstrup, 1856 (Sepiolidae; Cephalopoda). J Exp Mar Biol Ecol 372:75-81

Jackson GD, Jackson CH (2004) Mating and spermatophore placement in the onychoteuthid squid Moroteuthis ingens. J Mar Biol Assoc UK 84:783-784

Jackson GD, McKinnon JF, Lalas C, Ardern R, Buxton NG (1998) Food spectrum of the deepwater squid Moroteuthis ingens (Cephalopoda: Onychoteuthidae) in New Zealand Waters. Polar Biol 20:56-65

Kubodera T, Koyama Y, Mori K (2007) Observations of wild hunting behaviour and bioluminescence of a large deep-sea, eight-armed 
squid, Taningia danae. Proc $\mathrm{R}$ Soc Lond $\mathrm{B}$ Biol Sci 274(1613):1029-1034

Nesis KN (1970) Occurrence of a rare squid, Chaunoteuthis mollis Appellöf (family Onychoteuthidae) in the Indian Ocean. Veliger 12(3):290-292

Nesis KN (1987) Cephalopods of the world. T.F.H. Publications, Neptune City, NJ

Nesis KN (1995) Mating, spawning and death in oceanic cephalopods: a review. Ruthenica 6(1):23-64

Nesis KN, Nigmatullin CHM, Nikitina IV (1998) Spent females of deepwater squid Galiteuthis glacialis under the ice at the surface of the Weddell Sea (Antarctic). J Zool Lond 244:185-200

Norman MD, Lu CC (1997) Sex in giant squid. Nature 389:683-684

O'Shea S, Jackson GD, Bolstad KS (2007) The nomenclatural status, ontogeny and morphology of Pholidoteuthis massyae (Pfeffer, 1912) new comb (Cephalopoda: Pholidoteuthidae). Rev Fish Biol Fish 17:425-435

Okutani T (1974) Epipelagic decapod cephalopods collected by micronekton tows during the EASTROPAC expeditions, 1967-1968. Bull Tokai Reg Fish Res Lab 80:29-118

Okutani T, Ida H (1986) Rare and interesting squid in Japan-IX. A mass occurrence of Chaunoteuthis mollis Appellöf, 1891 (Oegopsida: Onychoteuthidae) from off Japan. Venus 45(1):53-60

Orsi Relini L (1995) Notes on midwater collections of Heteroteuthis dispar (Cephalopoda, Sepiolidae). Bull Inst Oceanogr 16:63-72

Quetglas A, Fliti K, Massutí E, Refes W, Guijarro B, Zaghdoudi S (2006) First record of Taningia danae (Cephalopoda: Octopoteuthidae) in the Mediterranean Sea. Sci Mar 70(1):153-155
Roper CFE, Vecchione M (1993) A geographic and taxonomic review of Taningia danae Joubin, 1931 (Cephalopoda: Octopoteuthidae), with new records and observations on bioluminescence. In: Okutani T, O'Dor RK, Kubodera T (eds) Recent advances in fisheries biology. Tokai University Press, Tokyo, pp 441-456

Santos MB, Pierce GJ, González ÁF, Santos F, Váquez MA, Santos MA, Collins MA (2001) First records of Taningia danae (Cephalopoda: Octopoteuthidae) in Galician waters (northwest Spain) and in Scottish waters (UK). J Mar Biol Assoc UK 81:355-356

Takahama H, Kinoshita T, Sato M, Sasaki F (1991) Fine structure of the spermatophores and their ejaculated forms, sperm reservoirs, of the Japanese common squid, Todarodes pacificus. J Morphol 207(3):241-252

Thompsett DH (1939) Sepia. M. B. C. Mem Typ Br Mar Pl Anim 32: $1-183$

Torchio M (1967) Eccezionale reperto di Chaunoteuthis mollis (Appelöff [sic]) nello Stretto di Messina (Cephalopoda: Dibranchiata). Natura (Milano) 58(3):193-207

Voss NA (1985) Systematics, biology and biogeography of the cranchid cephalopod genus Teuthowenia (Oegopsida). Bull Mar Sci 36(1): $1-85$

Young RE (1978) Vertical distribution and photosensitive vesicles of pelagic cephalopods from Hawaiian waters. Fish Bull US 76(3):583-615 